\title{
PROCESS AND DETERMINANTS OF CROSS-BORDER MIGRATION OF NEPALESE PEOPLE TO INDIA
}

\author{
Laxman Singh Kunwar*
}

\begin{abstract}
Cross border migration between Nepal and India has long history with unique dimensions. This paper highlights the migration process and determining factors of cross border migrants of Nepalese people to India. Some literatures related with migration between Nepal and India as well as main migration theories including their debates are highlighted. The study households were selected randomly by using systematic random sampling method. The information was collected through field study by using structured and semi structured questions. The participation of ancestors in cross border, sources of information, accompanies of migrants and decision makers for cross border migration were analyzed in migration process. Main reasons of crossing the border, employment situation, poverty and income, land holding size, indebtedness and frequencies of migrants crossing the border by themselves were concluded the main determining factors in cross border migration.
\end{abstract}

Key words: Cross border migration, poverty, indebtedness, employment.

\section{INTRODUCTION AND OBJECTIVE}

Migration is usually defined as the movement of people from one place to another seasonally, temporarily, and permanently, for a number of voluntary or involuntary reasons. Migration promotes exchange in work skills and experiences, enhances development of individuals, influences the size and shape of families, and age and sex composition. Migration has both positive and negative impacts on migrants themselves in their place of origins and destinations. The last two decades witnessed increase in the scale and complexity of international migration (Hugo, 2007). In 2005, the number of migrants worldwide was estimated at 185 to 192 million (IOM, 2005) and reached 258 million (regarded as migrants stock) people in 2017 which is accounted 3.4 per cent of world population (UN, 2017). Castles and Miller (2003) call the age of migration because people flows

* Dr. Kunwar is Associate Professor, Patan Campus, Patandhoka, T U. 
have become global and affect nearly all countries on earth, whether as sending, receiving or transit countries, or as a combination of these. Remittances have become focal point within the migration-development nexus. According to World Bank the total volume of remittance in 2010 was $\$ 467$ million and this volume has reached to \$ 594 million in 2017 (WB, 2017). Cross border migration of Nepalese people to India has long history with unique economic, social, cultural and religious purposes. There is lack of exact volume of cross-border migrants to India due to open border and lack of provisions of record keeping on entry and exit of people between two countries. The objectives of this paper are to identify the voluntary migration process to Nepalese people to India as well as to find out the main determining factors of cross-border migrants to India.

\section{REVIEW OF LITERATURE}

This sub section highlights the brief history of migration of Nepalese people to India, cross-border migration studies in Nepal, migration perspectives based on classical/neoclassical, Marxist/neo Marxist and theoretical debates on migration. The history of foreign employment in Nepal dates back almost 200 years, when Britain began recruiting men from the hill sides of Nepal into the British armed forces. After India's independence in 1947, the Indian military also began enlisting Nepali men. About 3,500 Nepali soldiers serve in the British army and more than 50,000 Nepalese are enlisted in the Indian military. India was the first country to attract civilian migrants from Nepal. The inflow of working migrants to India has increased sharply since the 1950s and 1960s. India is the largest destination country for Nepalese migrants (Seddon, 2005).

\section{Classical/Neo Classical Perspectives}

The 'laws of migration' formulated by Ravenstein (1885) is the oldest concept in understanding migration. According to this law, migration is an inseparable part of development and the major causes of migration were economic (Ravenstein 1885; 1889). The push-pull model is present in both origin and destination (Lee 1966). Lee (1966) revised Ravenstein's laws on migration and proposed that the decision to migrate is determined by factors associated with the area of origin and destination; intervening obstacles such as distance, physical barriers and immigration laws, and personal factors.

Harris-Todaro model (1970) remained the basis of neo-classical migration theory. It called for modifying simple wage differential approach 
not only looking at the prevailing income differentials but also rural-urban income differential adjusted for the probability of finding an urban job (Todaro, 1969). Borjas $(1989 ; 1990)$ postulated the idea of an international immigration market, in which potential migrants base the choice of destination on individual, cost and benefit calculations. Human capital framework treats migration as an investment. In economic theory, human capital has increasingly been recognized as a crucial factor in the process of economic development (Becker, 1962; Sjaastad, 1962).

\section{Marxist/Neo- Marxist Perspectives}

A radically different interpretation of migration was embedded in the intellectual root of Marxist political economy in 1960s known as historical-structural theory (Castles and Miller, 2003). It emerged in response to neo-classical approaches. Historical-structural theory postulated that economic and political power is unequally distributed among developed and underdeveloped countries, that people have unequal access to resources, and that capitalist expansion has the tendency to reinforce these inequalities. Instead of modernizing and gradually progressing towards economic development, underdeveloped countries are trapped by their disadvantaged position within the global geopolitical structure.

Migration is a direct result and cause of the circumstances of underdeveloped societies and the international division of labour. International capitalist penetration into these societies deepens; their labour migratory process intensifies, moving from an initial stage of low migration to increasing pressure for more and more migration (Porters, 1978; Zelinsky, 1971). Though, the uneven development process is not independent of the social relations of production but evolving spatial structure and relations are the key actors that induce migration (Amin, 1980; Lipton, 1977). Migrants are an integral part of such relations (Leeds, 1977). Marxists primarily concentrate on the colonial capitalist penetration into domestic modes of production in underdeveloped countries, and argued that the global colonial expansion following the industrial revolution was directly linked to over production and the falling rate of profits and hence a crisis in capital accumulation, and a growing mass of industrial reserve army or relative surplus population and consequent poverty and social conflicts between capital and labour. Colonialism and colonial migration has considered as a salvation to these problems (Marx, 1976). Migration is conditioned by the externally superimposed structural and materials forces, and is a form 
and mechanism of labour control by capital within the capitalist social formation (Wallerstein, 1974).

Wallerstein's $(1974,1980)$ world systems theory classified countries according to their degree of dependency, and distinguished between the capitalist core nations, followed by the semi peripheral, peripheral, and isolated nations in the external area, which were not yet included in the capitalist system. In this perspective, the incorporation of the peripheries into the capitalist economy is associated with putting migration drain on them, exactly the opposite of factor price equalization presumed by neoclassical theory.

Myrdal (1957) developed cumulative causation theory designed to explain the general perspective on the concentration of economic activities. Cumulative causation theory postulates that once differential growth had occurred, internal and external economies of scale will perpetuate and deepen the bipolar pattern characterized by the vicious cycle of poverty in the periphery and the accelerated growth of the core region (Potter, Bimmd, Elliot \& Smith 1999).

Frank $(1966,1969)$ was the frontrunner of the dependency theory and hypothesized that global capitalism contributed to the development of underdevelopment. The dependency school views migration not just as detrimental to the economies of underdeveloped countries but also as one of the very causes of underdevelopment, rather than as a path towards

\section{Theoretical Debates on Migration}

The debates on migration theories can be broadly distinguished in above two radically opposed approaches and summarized (Table 1).

Table 1: Opposing Views on Migration Theories

\begin{tabular}{|l|l|}
\hline Classical/Neo-classical & Marxist and Neo Marxist \\
\hline Functionalist & Structuralist \\
\hline Modernization & Disintegration \\
\hline Net North-South transfer & Net South-North transfer \\
\hline Brain gain & Brain drain \\
\hline More equality & More inequality \\
\hline Remittance investment & Consumption \\
\hline Development & Dependency \\
\hline Less migration & More migration \\
\hline
\end{tabular}

Source: de Hass, 2008 


\section{Cross-Border Migration Studies in Nepal and Review of Literature}

The movement of people between Nepal and India is largely facilitated by the open border between the two countries. Weiner (1971) examined the implication of internal migration and Indian immigration in social and political affairs of Nepal. He also dealt the migration of Nepalese nationals to India. The regional disparities between Hills and Tarai were the basic reason of internal migration. Low per unit arable land in Hill, employment opportunities outside the Hills and malaria eradication in Tarai were main reasons. The vast majority of external migrants go to India for in search of employment, both army and non-army to buy yearly needs of consumer goods, to supplement family incomes, to pay family debts, and to meet other cash needs (Macfarlane, 1976).

New Era (1981) analyzed the nature, extent, and impact of interregional migration relating to international migration in Nepal on the basis of censuses of 1952/54, 1961 and 1971. The study analyzed the process, patterns, causes and consequences of migration.

Gurung et al. (1983) have examined the nature, volume and causes and impact of economic and other concerned sectors and national policies on internal and international migration. The study was based on field survey of 2,411 household in three towns of Kathmandu valley and 5,651 household head in ten districts of Tarai. Positive and negative impacts of international migration were also been evaluated. Dahal (1978) analyzed the supply and demand factors of Indian immigrants in Tarai region of Nepal. Based on sample survey of four different wards of Katahari VDC of Morang district, he examined immigrant's impact on socio-economic sector and lives of Nepalese citizens. Kansakar (1982) described the historical perspectives of emigration of Nepalese people for recruitment in foreign armies since 1816 and the role of their remittances in development of Nepal.

Just as India was the main destination of absentees abroad, it was also the main source of the foreign-born population. The international boundary between Nepal and India does not regulate human movement. Neither is there any physical restriction (Gurung, 2001). Majority of migrant's destination are either urban centers of Nepal or crossing the border to India. The Suguolli Treaty of 1816 AD and later on the Peace and Friendship Treaty of 1950 AD has opened the door of cross-border migration between Nepal and India (Gurung et al., 1983). 


\section{PROCESS AND DETERMINANTS OF CROSS-BORDER ...}

Central Department of Population Studies (CDPS) concluded that more than 84 per cent out of total 1,057 emigrants' destination was India. Most of the emigrants to India were found illiterate or attained primary level of education. Very few proportion attained secondary level of education (KC et al., 1997).

According to the censuses 1952/54, 1981, 1991, 2001 and 2011of Nepal respectively recorded 198,120, 402,977, 658, 290 and 762,181 and $1,917,903$ absentee population. Out of total absentee population, India shared the major destination of absentee population and recorded as 79 per cent in 1952/54, 93 per cent in 1981, 89 per cent in 1991, 79 per cent in 2001 and 37.5 per cent in 2011 (CBS, 2014). The volume of crossborder migrants to India occupies major proportion among emigrants, but is in decreasing trends because of emerged trend of joining of Nepalese emigrants to the other countries, mainly to the Gulf region.

The migration literatures are broadly categories in the two groups which are the Classical/ Neo-Classical and Marxist/Neo Marxist perspectives.

\section{METHODOLOGY}

Preliminary field observation and consultation meeting with Chief District Officer (CDO), Local Development Officer (LDO), police officer, local political leaders and other relevant Government and non-government officials was carried out in three districts Baitadi, Surkhet and Kanchanpur was carried out in January, 2011. Daijee VDC, Kanchanpur was selected as appropriate field site on the basis of feedbacks received from field observation and consultation meetings. The total household $(3,712)$ of VDC was included in the study from the district profile and 50 per cent households were considered as cross border migrants households as per inputs received from consultations meetings. A simple formula was used to determine the number of households for the study purpose of this study.

$S S=\frac{Z^{2} \times p \times(1-p)}{C^{2}}$

Where,

$\mathrm{SS}=$ Sample Size (Number of households to be selected for the study)

$\mathrm{Z}=$ Confidence level (i.e. $95 \%, 99 \%$ expressed in 1.96, 2.58 respectively)

$\mathrm{p}=$ Prevalence of cross-border migrants

$\mathrm{C}=$ Confidence interval, expressed as decimal (e.g. $0.04= \pm 4)$ 
With this formula, the crude sample households for the study were, by assuming $\mathrm{Z}$ to be at 99 percent confidence level (i.e. 2.58), p to be 50 percent (i.e. 0.5) and $\mathrm{C}$ to be 4 (i.e. 0.04), as follows:

$$
\mathrm{SS}=\frac{\mathrm{Z}^{2} \times \mathrm{p} \times(1-\mathrm{p})}{\mathrm{C}^{2}}=\frac{2.58^{2} \times 0.5 \times 0.5}{0.04^{2}}=\frac{1.6641}{0.0016}=1040.06
$$

Once the crude sample size was determined, it was further corrected for the finite households using the following formula:

$$
\text { Final SS }=\frac{\mathrm{SS}}{1+\frac{\mathrm{SS}-1}{\mathrm{HH}}}
$$

Where,

Final SS = Final Sample Size (Number of households to be selected for the study)

$\mathrm{HH}=$ Total Households in the VDC

Final SS $=\frac{\mathrm{SS}}{1+\frac{\mathrm{SS}-1}{\mathrm{HH}}}=\frac{1040.06}{1+\frac{1040.06-1}{3712}}=\frac{1040.06}{1+\frac{1039.06}{3712}}=\frac{1040.06}{\frac{3712+1039.06}{3712}}=\frac{1040.06}{1.28}=812.54$

Final $\mathrm{SS} \cong 813$ and interviews were conducted for 809 households due to four households in the sample were found to be vacant.

Table 2: Ward Wise Distribution of Sample Households by Cross-Border Migration Status

\begin{tabular}{|l|c|c|c|c|c|c|c|c|c|c|}
\hline \multirow{2}{*}{ Migration Status } & \multicolumn{7}{|c|}{ Ward Number } & \multirow{2}{*}{ Total } \\
\cline { 2 - 12 } & $\mathbf{1}$ & $\mathbf{2}$ & $\mathbf{3}$ & $\mathbf{4}$ & $\mathbf{5}$ & $\mathbf{6}$ & $\mathbf{7}$ & $\mathbf{8}$ & $\mathbf{9}$ & \\
\hline Non Migrants & 61 & 6 & 82 & 63 & 31 & 62 & 24 & 43 & 51 & 423 \\
\hline Current Migrants & 16 & 15 & 32 & 50 & 22 & 45 & 18 & 15 & 18 & 231 \\
\hline Return Mirants & 14 & 3 & 14 & 21 & 13 & 22 & 2 & 10 & 16 & 115 \\
\hline $\begin{array}{l}\text { HH with Both (Return \& } \\
\text { Current Migrants) }\end{array}$ & 1 & 4 & 4 & 9 & 3 & 8 & 1 & 5 & 5 & 40 \\
\hline Total & $\mathbf{9 2}$ & $\mathbf{2 8}$ & $\mathbf{1 3 2}$ & $\mathbf{1 4 3}$ & $\mathbf{6 9}$ & $\mathbf{1 3 7}$ & $\mathbf{4 5}$ & $\mathbf{7 3}$ & $\mathbf{9 0}$ & $\mathbf{8 0 9}$ \\
\hline
\end{tabular}

Source: Field survey, 2011.

Out of 809 households, 386 households were cross-border migrants (current, return, and both current and return) households. From 386 households, 426 were involved in cross border migration to India. Separate sets of structures and semi structured questionnaires for current 
migrants, returned migrants and non migrants were designed. In addition, discussion guideline was developed to conduct focus group discussions (FGDs) and a separate guideline was prepared to carry out Key Informants Interviews (KIIs). This paper is based only on structure and semi structure questionnaires or quantitative information

\section{RESULT AND DISCUSSION}

The migration process involves networks that include relatives, neighbors and friends with migration experience, and informal and formal recruitment agents. In addition, ancestors and senior household members who have participated in cross-border migration in the past can be catalysts for migrants to take decision on cross border migration process.

Out of total 426 cross-border migrants, 172 (40.4\%) migrant's ancestors were found participating in cross-border migration to India, which composed $62(36 \%)$, and $110(64 \%)$ return and current migrants (Table, 3). More than two thirds of migrant's ancestors were participated in cross-border migration are indicative of high degree of continuity of crossborder migrants through generations. This represents the intra-generational transmission of negative and positive experiences of cross-border migration. Many migrant sending households have a migration 'tradition' which is transferred from one generation to the next.

Table 3: Distribution of Migrants According to Their Ancestors Participated in Cross-Border Migration

\begin{tabular}{|l|c|c|c|c|c|c|c|}
\hline \multirow{2}{*}{$\begin{array}{l}\text { Participation of Ancestors } \\
\text { Migration }\end{array}$} & \multicolumn{2}{|c|}{$\begin{array}{c}\text { Return } \\
\text { Migrants }\end{array}$} & \multicolumn{2}{c|}{$\begin{array}{c}\text { Current } \\
\text { Migrants }\end{array}$} & \multicolumn{2}{c|}{$\begin{array}{c}\text { Total } \\
\text { Migrants }\end{array}$} \\
\cline { 2 - 8 } & $\mathbf{N}$ & $\mathbf{\%}$ & $\mathbf{n}$ & $\mathbf{\%}$ & $\mathbf{N}$ & $\mathbf{\%}$ \\
\hline Yes & 62 & 40.0 & 110 & 40.6 & 172 & 40.4 \\
\hline No & 93 & 60.0 & 161 & 59.4 & 254 & 59.6 \\
\hline Total & $\mathbf{1 5 5}$ & $\mathbf{1 0 0 . 0}$ & $\mathbf{2 7 1}$ & $\mathbf{1 0 0 . 0}$ & $\mathbf{4 2 6}$ & $\mathbf{1 0 0 . 0}$ \\
\hline If Yes, Since When? & 9 & 14.5 & 14 & 12.7 & 23 & 13.4 \\
\hline Before my grandfather's time & 95 & 40.3 & 42 & 38.2 & 67 & 39.0 \\
\hline $\begin{array}{l}\text { During my grandfather's } \\
\text { time }\end{array}$ & 25 & 45.2 & 54 & 49.1 & 82 & 47.6 \\
\hline From my father's time & 28 & $\mathbf{6 2}$ & $\mathbf{1 0 0 . 0}$ & $\mathbf{1 1 0}$ & $\mathbf{1 0 0 . 0}$ & $\mathbf{1 7 2}$ & $\mathbf{1 0 0 . 0}$ \\
\hline Total & \multicolumn{7}{|l|}{} \\
\hline
\end{tabular}

Source: Field survey, 2011. 
The social network helps to explain the migration. For about 40 percent of cross border migrants, friends were their source of information followed by family members $(26.5 \%)$, relatives, and about 9 percent of previous migrants (Table 4). The sources of information also were from Meith (person who played role in cross border migration process or labour contractor) who receives commission from both employers and migrants.

Table 4: Distribution of Cross-Border Migrants According to Their Sources of Information

\begin{tabular}{|l|c|c|c|c|c|c|}
\hline \multirow{2}{*}{$\begin{array}{l}\text { Sources of Information of } \\
\text { Cross-border Migrants }\end{array}$} & \multicolumn{2}{|c|}{$\begin{array}{c}\text { Return } \\
\text { Migrants }\end{array}$} & \multicolumn{2}{c|}{$\begin{array}{c}\text { Current } \\
\text { Migrants }\end{array}$} & \multicolumn{2}{c|}{$\begin{array}{c}\text { Total } \\
\text { Migrants }\end{array}$} \\
\cline { 2 - 8 } & $\mathbf{N}$ & $\mathbf{\%}$ & $\mathbf{n}$ & $\mathbf{\%}$ & $\mathbf{N}$ & $\mathbf{\%}$ \\
\hline Friends & 62 & 40.0 & 107 & 39.5 & 169 & 39.7 \\
\hline Family members & 28 & 18.1 & 85 & 31.4 & 113 & 26.5 \\
\hline Relatives & 25 & 16.1 & 73 & 26.9 & 98 & 23.0 \\
\hline Worked there before & 36 & 23.2 & - & - & 36 & 8.5 \\
\hline Meith & 4 & 2.6 & 5 & 1.8 & 9 & 2.1 \\
\hline Manpower/ agent & - & - & 1 & 0.4 & 1 & 0.2 \\
\hline Total & $\mathbf{1 5 5}$ & $\mathbf{1 0 0 . 0}$ & $\mathbf{2 7 1}$ & $\mathbf{1 0 0 . 0}$ & $\mathbf{4 2 6}$ & $\mathbf{1 0 0 . 0}$ \\
\hline
\end{tabular}

Source: Field survey, 2011.

Migration is a process of social change where an individual, alone or accompanied by others, because of one or more reasons of economic betterment, political upheaval, education or other purposes, people leaves one geographical area for prolonged stay or permanent settlement in another geographical area. Out of total 426 total migrants, about 36 percent reported that they joined alone in their working place in India, 31 per cent were accompanied by friends, 17 per cent accompanied by relatives, 15 per cent accompanied by family members and only two per cent by Meith (Table 5).

Table 5: Distribution of Cross-Border Migrants According to their Accompanies while Joining to Work in India

\begin{tabular}{|l|c|c|c|c|c|c|}
\hline \multirow{2}{*}{$\begin{array}{l}\text { Accompanies of Cross-border } \\
\text { Migrants While Joining to Work }\end{array}$} & \multicolumn{2}{|c|}{$\begin{array}{c}\text { Return } \\
\text { Migrants }\end{array}$} & \multicolumn{2}{c|}{$\begin{array}{c}\text { Current } \\
\text { Migrants }\end{array}$} & \multicolumn{2}{c|}{$\begin{array}{c}\text { Total } \\
\text { Migrants }\end{array}$} \\
\cline { 2 - 8 } & $\mathbf{N}$ & $\mathbf{\%}$ & $\mathbf{n}$ & $\mathbf{\%}$ & $\mathbf{N}$ & $\mathbf{\%}$ \\
\hline Alone & 53 & 34.2 & 100 & 36.9 & 153 & 35.9 \\
\hline Friends & 56 & 36.1 & 75 & 27.7 & 131 & 30.8 \\
\hline Relatives & 24 & 15.5 & 48 & 17.7 & 72 & 16.9 \\
\hline Family members & 17 & 11.0 & 45 & 16.6 & 62 & 14.5 \\
\hline Meith & 5 & 3.2 & 3 & 1.1 & 8 & 1.9 \\
\hline Total & $\mathbf{1 5 5}$ & $\mathbf{1 0 0 . 0}$ & $\mathbf{2 7 1}$ & $\mathbf{1 0 0 . 0}$ & $\mathbf{4 2 6}$ & $\mathbf{1 0 0 . 0}$ \\
\hline
\end{tabular}

Source: Field survey, 2011. 
Demographic attributes, life- cycle stage, attachment to place, social capital and environmental values, drive migration decisions. Cross border migrants themselves are mainly responsible to carry out decision in migration process. Out of total cross border migrants, almost two thirds made their own decision to migrate for work in India. Parents and spouse together account for about one third of the cross border migrants to decide to migrate to India for work (Table 5).

Table 6: Distribution of Decision Maker of Cross-Border Migrants in Migration Process

\begin{tabular}{|c|c|c|c|c|c|c|}
\hline \multirow[t]{2}{*}{$\begin{array}{l}\text { Decision } \\
\text { Migrants }\end{array}$} & \multicolumn{2}{|c|}{$\begin{array}{c}\text { Return } \\
\text { Migrants }\end{array}$} & \multicolumn{2}{|c|}{$\begin{array}{l}\text { Current } \\
\text { Migrants }\end{array}$} & \multicolumn{2}{|c|}{$\begin{array}{c}\text { Total } \\
\text { Migrants }\end{array}$} \\
\hline & $\mathrm{n}$ & $\%$ & $\mathbf{N}$ & $\%$ & $\mathbf{N}$ & $\%$ \\
\hline Self & 98 & 63.2 & 185 & 68.3 & 283 & 66.4 \\
\hline Parents & 34 & 21.9 & 60 & 22.1 & 94 & 22.1 \\
\hline Spouse & 23 & 14.8 & 20 & 7.4 & 43 & 10.1 \\
\hline Friends/ accompanies & - & - & 4 & 1.5 & 4 & 0.9 \\
\hline $\begin{array}{l}\text { Seniors/ respected persons } \\
\text { of community }\end{array}$ & - & - & 2 & 0.7 & 2 & 0.5 \\
\hline Total & 155 & 100.0 & 271 & 100.0 & 426 & 100.0 \\
\hline
\end{tabular}

Source: Field survey, 2011.

Various factors such as employment opportunities, wage levels, land ownership, transport and communication, kinship ties, inheritance system, community facilities, and ethnic composition influence the decision of cross-border migration going to India for work. Personal and household characteristics are also important determinants of cross-border migration. In the study area, 27.7 per cent of decided to go to India for they did not need passport and visa followed by easy to work (23.7\%), presence of family members (17.1\%), presence of neighbors/friends, $(16.2 \%)$ and ancestral flow (14.8\%) (Table 7). 
Table 7: Distribution of Cross-Border Migrants by Reasons for Choosing India

\begin{tabular}{|l|c|c|c|c|c|c|}
\hline \multirow{2}{*}{ Reasons for Choosing India } & \multicolumn{2}{|c|}{$\begin{array}{c}\text { Return } \\
\text { Migrants }\end{array}$} & \multicolumn{2}{c|}{$\begin{array}{c}\text { Current } \\
\text { Migrants }\end{array}$} & \multicolumn{2}{c|}{$\begin{array}{c}\text { Total } \\
\text { Migrants }\end{array}$} \\
\cline { 2 - 8 } & $\mathbf{N}$ & $\mathbf{\%}$ & $\mathbf{n}$ & $\mathbf{\%}$ & $\mathbf{N}$ & $\mathbf{\%}$ \\
\hline $\begin{array}{l}\text { Less administrative problems (no need of } \\
\text { passport \& visas) }\end{array}$ & 46 & 29.7 & 72 & 26.7 & 118 & 27.7 \\
\hline Cheap process/ easy to work & 38 & 24.5 & 63 & 23.2 & 101 & 23.7 \\
\hline Presence of family members and relatives & 19 & 12.3 & 54 & 19.9 & 73 & 17.1 \\
\hline Presence of neighbours/ friends & 25 & 16.1 & 44 & 16.2 & 69 & 16.2 \\
\hline Ancestral flow (cross-border migration) & 25 & 16.1 & 38 & 14.0 & 63 & 14.8 \\
\hline Prior information available & 2 & 1.3 & - & - & 2 & 0.5 \\
\hline Total & $\mathbf{1 5 5}$ & $\mathbf{1 0 0 . 0}$ & $\mathbf{2 7 1}$ & $\mathbf{1 0 0 . 0}$ & $\mathbf{4 2 6}$ & $\mathbf{1 0 0 . 0}$ \\
\hline
\end{tabular}

Source: Field survey, 2011.

Lack of employment opportunity in the study area was the dominant reason for cross-border migration to India. More than two-third $289(67.8 \%)$ cross-border migrants reported that their reason behind crossborder migration to India was lack of employment opportunity in their place of residence. This was followed by debt (13.6\%), to increase household income $(7.7 \%)$, and friends and accompany $(6.3 \%)$. Other reasons are relatively less important (Table 8 ).

Table 8: Distribution of Cross-Border Migrants According to Their Reasons for Migration

\begin{tabular}{|l|c|c|c|c|c|c|}
\hline \multirow{2}{*}{ Reasons of Cross-border migration } & \multicolumn{2}{|c|}{$\begin{array}{c}\text { Return } \\
\text { Migrants }\end{array}$} & \multicolumn{2}{c|}{$\begin{array}{c}\text { Current } \\
\text { Migrants }\end{array}$} & \multicolumn{2}{c|}{$\begin{array}{c}\text { Total } \\
\text { Migrants }\end{array}$} \\
\cline { 2 - 8 } & $\mathbf{N}$ & $\mathbf{\%}$ & $\mathbf{N}$ & $\mathbf{\%}$ & $\mathbf{N}$ & $\mathbf{\%}$ \\
\hline Lack of employment (here) & 99 & 63.9 & 190 & 70.1 & 289 & 67.8 \\
\hline Due to debt & 20 & 12.9 & 38 & 14.0 & 58 & 13.6 \\
\hline To increase household income & 16 & 10.3 & 17 & 6.3 & 33 & 7.7 \\
\hline Friends/accompany & 11 & 7.1 & 16 & 5.9 & 27 & 6.3 \\
\hline Employment opportunities (India) & 5 & 0.3 & 3 & 1.1 & 8 & 1.9 \\
\hline For child's Education & 1 & 0.6 & 6 & 2.2 & 7 & 1.6 \\
\hline $\begin{array}{l}\text { Due to conflict/ political instability } \\
\text { (here) }\end{array}$ & 2 & 1.3 & 1 & 0.3 & 3 & 0.7 \\
\hline Generational (ancestors) practice & 1 & 0.6 & - & - & 1 & 0.2 \\
\hline Total & $\mathbf{1 5 5}$ & $\mathbf{1 0 0 . 0}$ & $\mathbf{2 7 1}$ & $\mathbf{1 0 0 . 0}$ & $\mathbf{4 2 6}$ & $\mathbf{1 0 0 . 0}$ \\
\hline
\end{tabular}

Source: Field survey, 2011. 
Out of total of 386 migrant households, almost 90 per cent expressed no alternative to cross-border migration, mainly because of poverty of the household in the origin (74.4\%) and lack of employment opportunity at home (24.1\%) (Table 9)

Table 9: Distribution of Households with Reasons for Cross-Border Migration of Their Family Members

\begin{tabular}{|l|c|c|c|c|c|c|c|c|}
\hline $\begin{array}{l}\text { Having no } \\
\text { Alternatives of } \\
\begin{array}{l}\text { Cross-border } \\
\text { Migration }\end{array}\end{array}$ & $\begin{array}{l}\text { HH with } \\
\text { return } \\
\text { migrants }\end{array}$ & $\begin{array}{c}\text { HH with } \\
\text { current } \\
\text { migrants }\end{array}$ & $\begin{array}{c}\text { HH with } \\
\text { both } \\
\text { current } \\
\text { \& return) } \\
\text { migrants }\end{array}$ & \multicolumn{2}{|c|}{ Total } \\
\cline { 2 - 11 } & N & \% & N & \% & N & \% & N & $\%$ \\
\hline Yes & 94 & 81.7 & 211 & 91.3 & 39 & 97.5 & 344 & 89.1 \\
\hline No & 21 & 18.3 & 20 & 8.7 & 1 & 2.5 & 42 & 10.9 \\
\hline Total & $\mathbf{1 1 5}$ & $\mathbf{1 0 0 . 0}$ & $\mathbf{2 3 1}$ & $\mathbf{1 0 0 . 0}$ & $\mathbf{4 0}$ & $\mathbf{1 0 0 . 0}$ & $\mathbf{3 8 6}$ & $\mathbf{1 0 0 . 0}$ \\
\hline If Compulsion what are the reasons behind it? \\
\hline Poverty & 68 & 72.3 & 157 & 74.4 & 31 & 79.5 & 256 & 74.4 \\
\hline Unemployment & 24 & 25.6 & 51 & 24.2 & 8 & 20.5 & 83 & 24.1 \\
\hline $\begin{array}{l}\text { Had to earn for family } \\
\text { members education }\end{array}$ & 2 & 2.1 & 1 & 0.5 & - & - & 3 & 0.9 \\
\hline Political conflict & - & - & 2 & 1.0 & - & - & 2 & 0.8 \\
\hline Total & $\mathbf{9 4}$ & $\mathbf{1 0 0 . 0}$ & $\mathbf{2 1 1}$ & $\mathbf{1 0 . 0}$ & $\mathbf{3 9}$ & $\mathbf{1 0 0 . 0}$ & $\mathbf{3 4 4}$ & $\mathbf{1 0 0 . 0}$ \\
\hline
\end{tabular}

Source: Field Survey, 2011.

Sawhill \& Isabel (1988) discussed how income and needs are affected by short-term economic factors such as employment availability and wage levels; long-term economic factors such as education and training; demographic factors such as marriage, fertility, and migration; and programmatic factors such as tax rates and public assistance. A drop in income leads to a relatively large contemporaneous reduction in consumption due to abject poverty and food deficit. Different income groups also have different propensities to migrate. There seems to be theoretical and empirical regularity that the poorest are less capable of migrating due to burdens of costs and risks (de Haas, Carlos \& Simona, 2009). The existing low income situation of study households was considered the one of the determinant factor of cross border migration to India. Among the migrants 
households 98.5 per cent were compelled to migrate to India due to poverty and unemployment which reflects the situation of low income (Table 9).

Income from agriculture is not sufficient for marginal and small land holders. The volume of cross-border migrants in the study area was low among landless and small land owners with less than 5 Kattha of land. The volume of migrants was high among land size holders 5 to less than 10 and 10 to less than 20 Kattha of land size. The volume of migrants decreased to households having land size more than 20 Kattha of land. The relationship between land and cost of migration (Winters, de jauvry \& sadoulet, 2001), indicates an ability to finance migration regardless of the distance and the destination. The cost of migration constrains the decision to migrate for landless and marginal land holders.

Among the study households nearly 58 per cent were indebted (Table 10). Rural households are extremely under the pressure of debt and structural adjustment (Bryceson, 1995). Ahlburg and Brown (1998) hypothesized that remittance receiving households maintained the migrant's social ties, connections and standing in the home community. Many times the migrant is in debt to the household to which it remits; these implicit loans could have resulted from the household paying for an education or the cost to migrate.

Table 10: Distribution of Households by Indebtedness Status

\begin{tabular}{|c|c|c|c|c|c|c|c|c|c|c|}
\hline \multirow[t]{2}{*}{$\begin{array}{c}\text { Having } \\
\text { Debt }\end{array}$} & \multicolumn{2}{|c|}{$\begin{array}{c}\text { Non } \\
\text { Migrants } \\
\text { HH } \\
\end{array}$} & \multicolumn{2}{|c|}{$\begin{array}{c}\text { Return } \\
\text { Migrants } \\
\text { HH }\end{array}$} & \multicolumn{2}{|c|}{$\begin{array}{c}\text { Current } \\
\text { Migrants } \\
\text { HH }\end{array}$} & \multicolumn{2}{|c|}{$\begin{array}{c}\text { Both } \\
\text { Migrants } \\
\text { HH } \\
\end{array}$} & \multicolumn{2}{|c|}{ Total } \\
\hline & $\mathbf{N}$ & $\%$ & $\mathbf{N}$ & $\%$ & $\mathbf{N}$ & $\%$ & $\mathbf{N}$ & $\%$ & $\mathbf{N}$ & $\%$ \\
\hline Yes & 213 & 50.3 & 74 & 64.3 & 149 & 64.5 & 31 & 77.5 & 467 & 57.7 \\
\hline No & 210 & 49.7 & 41 & 35.7 & 82 & 34.5 & 9 & 22.5 & 342 & 42.3 \\
\hline Total & 423 & 100.0 & 115 & 100.0 & 231 & 100.0 & 40 & 100.0 & 809 & 100.0 \\
\hline
\end{tabular}

Source: Field survey, 2011.

More than 85 per cent of migrants have crossed the border for more than 2 times to 11 times (Table 11). This shows that individual's history of past mobility has developed social networks in several geographical locations. They know how to build and maintain social networks. For these people, the psychosocial costs of mobility are likely to be lower and have better information based on personal experience concerning the various cost-aspects of migration, and are consequently better able to evaluate the 
costs and benefits of mobility. They are more aware of their employment opportunities, and how to optimize work and income conditions. If better opportunities arise, they may change employers again. Therefore, people who moved for work-related reasons are more likely expected to express the intention to move again, while people who moved for demographic or family reasons are less likely to express such intentions.

Table 11: Distribution of Cross-Border Migrants According to their Frequencies of Crossing the Border to Join Work

\begin{tabular}{|l|c|c|c|c|c|c|}
\hline \multirow{2}{*}{$\begin{array}{c}\text { Frequencies of Crossing } \\
\text { border to Work }\end{array}$} & \multicolumn{2}{c|}{$\begin{array}{c}\text { Return } \\
\text { Migrants }\end{array}$} & \multicolumn{2}{c|}{$\begin{array}{c}\text { Current } \\
\text { Migrants }\end{array}$} & \multicolumn{2}{c|}{$\begin{array}{c}\text { Total } \\
\text { Migrants }\end{array}$} \\
\cline { 2 - 7 } & $\mathbf{n}$ & $\mathbf{\%}$ & $\mathbf{N}$ & $\mathbf{\%}$ & $\mathbf{N}$ & $\mathbf{\%}$ \\
\hline Once/ first time & 17 & 11.0 & 45 & 16.6 & 62 & 14.6 \\
\hline 2-5 times & 56 & 36.1 & 101 & 37.3 & 157 & 36.9 \\
\hline 6-10 times & 32 & 20.6 & 68 & 25.1 & 100 & 23.5 \\
\hline 11+ times & 50 & 32.3 & 57 & 21.0 & 107 & 25.0 \\
\hline Total & $\mathbf{1 5 5}$ & $\mathbf{3 6 . 4}$ & $\mathbf{2 7 1}$ & $\mathbf{6 3 . 6}$ & $\mathbf{4 2 6}$ & $\mathbf{1 0 0 . 0}$ \\
\hline
\end{tabular}

Source: Field survey, 2011.

The season/time of joining their working place by crossing the border from migrant's households showed that 51 percent of households left their homes during the agriculturally off seasons at their place of origin. Another 48 per cent, however, remain at home by giving priority to their own agricultural work. The decision of households to migrate is also influenced by availability of work at their destination (Table 12).

Table 12: Distribution of Households According to Their Season/Time of Participation in Cross-Border Migration

\begin{tabular}{|c|c|c|c|c|c|c|c|c|}
\hline \multirow[t]{2}{*}{$\begin{array}{l}\text { Season/Time } \\
\text { Participation }\end{array}$} & \multicolumn{2}{|c|}{$\begin{array}{l}\text { HH with } \\
\text { return } \\
\text { migrants }\end{array}$} & \multicolumn{2}{|c|}{$\begin{array}{l}\text { HH with } \\
\text { current } \\
\text { migrants }\end{array}$} & \multicolumn{2}{|c|}{$\begin{array}{l}\text { HH with both } \\
\text { (current \& } \\
\text { return) migrants }\end{array}$} & \multicolumn{2}{|c|}{ Total } \\
\hline & $\mathbf{N}$ & $\%$ & $\mathbf{N}$ & $\%$ & $\mathbf{n}$ & $\%$ & $\mathbf{N}$ & $\%$ \\
\hline $\begin{array}{l}\text { During agriculture off } \\
\text { season }\end{array}$ & 69 & 60.0 & 104 & 45.0 & 24 & 60.0 & 197 & 51.0 \\
\hline Unsure/ in all seasons & 45 & 39.1 & 124 & 53.7 & 16 & 4.0 & 185 & 47.9 \\
\hline $\begin{array}{l}\text { During time of } \\
\text { cultivation/harvesting }\end{array}$ & 1 & 0.9 & 3 & 1.3 & - & - & 4 & 1.1 \\
\hline Total & 115 & 100.0 & 231 & 100.0 & 40 & 100.0 & 386 & 100.0 \\
\hline
\end{tabular}

Source: Field survey, 2011. 
In the Nepalese context, country has long history of cross-border migration to India and foreign labour occupation has been an emerging issue. The irregularities of cross border migration, problems faced by migrants before migration and returning back from India are not properly addressed from the policy level. The migration process and main determining factors of Nepalese cross border migrants to India has no enough information. Agricultural based economy has turned toward remittance based economy. No any treaty existing between Nepal and India ever mentioned for the regulation of the Nepal-India border and management of cross border migrants.

Cross-border migration of people between Nepal and India and their process and determinants have not been studied in any detail. Crossborder migration, with its intricate web of demographic, social, economic and political determinants and consequences, is the topic that has moved to the forefront of the national and international agenda. There has been little research in Nepal on the process and determinants of cross border migration on the migrants themselves, to their household and community. Globally, the volume of international migrants has been increasing. The migration process and determining factors of Nepalese cross border migrants to India has unique dimension. The role of intra-generation migration, networks, poverty, indebtedness, land holding size, role of off farming seasons and frequency of crossing border have significantly contributed to facilitate cross border migration.

The overall goal of the study was to determine the major process and determining factors cross border migration of Nepalese people to India. The study provides feedback to analyze the Nepal -India relation in a new dimension mainly in the area of cross border migration of people of both countries and existing open border between two countries.

\section{REFERENCES}

Ahlburg, D. \& Brown R. (1998). Migrants' intentions to return home and capital transfers: Study of Tongans and Samoans in Australia. The Journal of Development Studies, 35:125-51.

Amin, S. (1980).Class and nation: Historically and in the current crisis. New York: Monthly Review Press.

Becker G.S. (1962). Investments in human capital: A theoretical analysis. Journal of Political Economy 70:9-49. 


\section{PROCESS AND DETERMINANTS OF CROSS-BORDER ...}

Borjas G.J. (1989). Economic theory and international migration. International Migration Review, New York: Center for Migration Studies. 23:457-85.

- - (1990). Friend or strangers: The impact of immigrants on the US economy. New York: Basic Books.

Bryceson, D.F. (1995). Wishful thinking: Western donor efforts to raise women's status'. In Bryceson, D.F. (Ed.), Women wielding the hoe: Lessons from rural Africa for feminist theory and development practice, Oxford: Berg Publishers.

Casteles, S., M. J. Miller (2003). The age of migration. New York: Guilford Press.

Central Bureau of Statistics (CBS) (2014). Population monograph of Nepal, Vol. I, Kathmandu: National Planning Commission Secretariat, Government of Nepal.

Dahal, D. R. (1978). Indian ethnic groups in the Nepal Tarai: A study of immigration pattern and socio-economic behaviour. (Part I, Eastern Tarai Sector). Kathmandu: Research Center for Nepal and Asian Studies, T. U

De Haas H. (2008). Irregular migration from West Africa to the Maghreb and the European Union: An overview of recent trends, Geneva: International Organization for Migration.

De Haas, H., C. V. \& S. V. (2009). Global migration futures: A conceptual and methodological framework for research and analysis Oxford: International Migration Institute.

Frank A.G. (1966).The development of underdevelopment. New York: Monthly Review Press.

- - (1969). Capitalism and underdevelopment in latin America. New York: Monthly Review Press.

Gurung, H. (2001). Highlands of the move: The migration trends in Nepal. .Aspects of Migration and Mobility in Nepal. Kathmandu: Ratna Pustak Bhandar. 11-42.

Gurung, H., B. K., C. B. Shrestha, Mishra C., Ojha D. P., Timilsina P. P., Gurung S. B. \& Kansakar V.B.S. (1983). Internal and international migration in Nepal. Kathmandu: National Commission on Population. 
Harris J. R., Todaro M. P. (1970). Migration, unemployment and development: A two-sector analysis. American Economic Review 60:126-42

Hugo, G. (2007). International migration and development in Asia, presentation to $8^{\text {th }}$ international conference of the Asia Pacific migration research network on the theme of 'migration, development and poverty reduction, Fuzhou, China, Retrieved Jan. 18, 2017 from 25-29 May 2007, http://apmrn.usp.ac.fj/conferences/8thAP MRNconference/1.Hugo.pdf,

International Organisation for Migration (IOM) (2005).Cross-border labour migration flows, Croatia-Italy: Focus on shipbuilding, Geneva: International Organization of Migration.

Kansakar, V. B. S (1982). Emigration, remittances and rural development. Kathmandu: Centre for Economic Development and Administration.

KC, B. K., Subedi B. P., Gurung Y. P., Acharya B., Suwal B. R. (1997). Migration situation in Nepal. Kathmandu: Ministry of Population and Environment, HMG, and UNFPA.

Lee E. S. (1966). A theory of migration. Demography 3:47-57

Leeds, A. (1977). Mythos and pathos: Some unpleasantries on peasantries. In R. Halperin and J. Dow (Eds.) Peasant livelihood, New York: St. Martin Press.

Lipton, M. (1977). Why poor people stay poor: A study of urban bias in world development. London: Temple Smith.

Macfarlane, A. (1976). Resources and population: A study of the gurungs of Nepal. London: Cambridge University Press.

Marx, K. (1976). Preface and introduction to a contribution to the critique of political economy. Peking: Foreign Language press.

Myrdal G. (1957). Rich lands and poor. New York: Harper and Row.

New Era (1981). Study on inter-regional migration in Nepal. Kathmandu: National Planning Commission.

Porters, A. (1978). Contemporary immigration: Theoretical perspectives on its Determinants and modes of incorporation. International Migration Review 23:606-30.

Potters R. B., Binns T., Elliot J. A. \& Smith D. (1999). Geographies of development. Harlow, England: Prentice Hall. 


\section{PROCESS AND DETERMINANTS OF CROSS-BORDER ...}

Ravenstein E.G. (1885). The laws of migration. Journal of the Royal Statistical Society 48:167- 227.

- - (1889). The laws of migration. Journal of the Royal Statistical Society 52:214- 301 .

Sawhill, Isabel V. (1988), Poverty in U.S: Why did it so persistent? Journal of Economic Literature, 26 (3), 1073-1119.

Sheddon, D. (2005). Nepal's dependence on exporting labor. Washington DC:Migration Policy Institute.

Sjaastad A. H. (1962). The costs and returns of human migration. Journal of Political Economy 70:80-93.

Todaro, M. P. (1969). A model of labor migration and urban unemployment in less-developed countries. American Economic Review 59:13848.

UN (2017). International migrtaion report. New York: Department of Economic and Social Affairs.

Wallerstein I. (1974). The modern world system I, Capitalist agriculture and the origins of the european world economy in the sixteenth century. New York: Academic Press.

- - - (1980). The modern world system II, Mercantilism and the consolidation of the European world-economy, 1600-1750. New York: Academic Press.

Weing, Myron (1971). The political and demography of Nepal. Population and Development Review. Kathmandu: CEDA, 99-124.

Winters, P., A. de Janvry, \& Sadoulet E. (2001). Family and community networks in Mexico- US migration. Journal of Human Resources 36(1):159-184.

World Bank (2017). Migration and remittances, recent development outlook. New work: Migration andDevelopment Brief-27.

Zelinsky, Z. (1971). The hypothesis of the mobility transition. Geographical Review 61:219-49. New York: American Geographical Society. 